\title{
Organizational structure of the news organizations; worldwide view
}

\author{
Rehab Hany \\ Assistant lecturer, Journalism \\ department , Cairo University
}

Introduction:

Primarily the aim of this paper is to have a worldwide view about different organizational structures in the news organizations that have common conditions with Egypt, also to go through papers that tried to map out the countries that we will go through in relevance to political, economical and journalistic environments.

After going through several papers the researcher decided to tackle these three dimensions that will include

a) Political environment

b) Economical environment

c) Journalistic environment

The researcher tried to find common grounds between similar case studies to Egypt and found that the nearest ones include the following countries:

a) Political environment:

*Tunisia

*France

* Poland

b) Economical environment:

*Greece

c) Journalistic environment:

*Russia 
a) Political environment:

*Tunisia

*France

* Poland

b) Economical environment:

*Greece

c) Journalistic environment:

*Russia

\section{a) Political environment:}

\section{*Tunisia}

The Tunisian Republic, its capital is Tunis with a population of 10.7 million.

Area $164,150 \mathrm{sq} \mathrm{km}(63,378 \mathrm{sq}$ miles $)$

Its major languages Arabic (official), French, major religion Islam ${ }^{(1)}$.

\section{Historical background:}

Home of the ancient city of Carthage, Tunisia was once an important player in the Mediterranean, thanks to its location in the centre of North Africa, close to vital shipping routes.

The Romans, Arabs, Ottoman Turks and French realized its strategic significance, making it a hub for control over the region.

French colonial rule ended in 1956, and Tunisia was led for three decades by Habib Bourguiba, who advanced secular ideas, foremost of which was the emancipation of women.

Mass protests unseated President Ben Ali in 2011 - the first of a series of popular uprisings to sweep the region ${ }^{(2)}$.

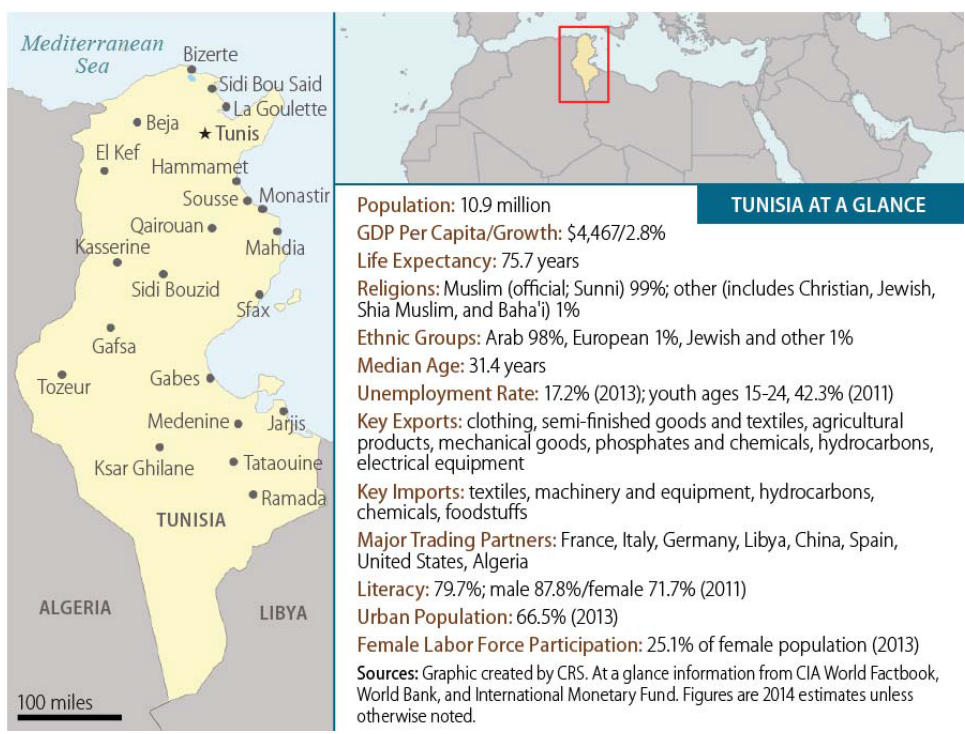


The country's transition has been relatively peaceful, but secular Tunisians, especially women, are worried about the growing influence of ultra-conservative Islamists. And there is a mounting challenge posed by Islamist militants who claimed responsibility for attacks in 2015 in which 60 people were killed, most of them foreigners ${ }^{(3)}$.

According to the constitution of 1959, Tunisia is an Islamic republic, although since independence it has been a thoroughly secular state. The president, who is chief of state, must be a Muslim and a Tunisian citizen, born of a Tunisian father and grandfather, and at least 40 years old. He serves a five-year term. The president enjoys extensive powers, initiating and directing state policy and appointing judges, provincial governors, the mayor of Tunis, and other high officials, the cabinet, headed by a prime minister, varies in size and is under presidential domination.

\section{POLITICAL PARTIES}

The Constitutional Democratic Rally (RCD) dominates the country's political life. Its leader from its founding as the Neo-Destour Party in 1934 to 1987 was Habib Bourguiba $^{(5)}$. In the first national elections in 1956, all 98 seats in the National Assembly were won by the National Union, a united front of the Neo-Destour Party with the UGTT, the National Union of Tunisian Farmers, and the Tunisian Union of Craftsmen and Merchants. In the November 1959 elections for the National Assembly, the Communist Party (Parti Communiste Tunisien) presented a list of 13 candidates in Tunis and Gafsa; elsewhere, the Neo-Destour Party was unopposed, and the ruling party won all 90 seats at stake. From 1959 to 1994, the RCD (acting in 1981 as part of a National Front with the UGTT) held a monopoly of Assembly seats ${ }^{(6)}$.

Banned in 1963, the Communist Party was the first opposition group to be fully legalized under the political liberalization of 1981. Two other parties, the Movement of Social Democrats (Mouvement des Démocrates Socialistes-MDS) and the Party of Popular Unity (Parti de l'Unité Populaire-PUP), failed to retain their provisional authorization when each fell short of receiving a $5 \%$ share of the total vote in the November 1981 election but nevertheless were formally legalized in 1983. The principal Islamist party, an-Nahda, has been outlawed. In 1992, it was hit hard by the jailing of many of its senior leaders ${ }^{(7)}$.

Due to a change in the 1994 electoral code to guarantee the opposition would win seats, opposition parties such as the Movement of Social Democrats (MDS) entered the Chamber of Deputies. As of 2006, there were seven officially recognized opposition parties: MDS, PUP, the Union of Democratic Unionists (UDU), Ettajdid (also called the Renewal Movement), the Social Democratic Liberal Party (PSDL), plus the Democratic Progressive Party (PDP) and the Democratic Forum for Labor and Liberties (FDTL), the only two not represented in the Chamber of Deputies as of the October 2004 elections. The RCD held 152 of the 182 seats as of 2006 . The Islamist an-Nahda remained an outlawed party. 


\section{The organizational structure of the Tunisian media:}

The Tunisian media have not had a similar cultural weight outside Tunisian borders ${ }^{8}$. Nevertheless, Tunisia has played a distinctive role in modern regional politics, particularly in the period when Egypt was ostracized after the Camp David accords and Tunis hosted the Arab League headquarters, and in the 1980s and early 1990s when it hosted the Palestine Liberation Organization.

Under the French protectorate $(1881-1956)^{(9)}$ Tunisian intellectuals developed newspapers whose content was nevertheless controlled by the French. After independence, President Bourguiba fostered an active mixed public and private, but all state-managed, press, described by Rugh as "uniform" $(2004,147)^{(10)}$. During the 1970 s there was some political pluralization and a corresponding relative opening of the press. When Ben Ali replaced Bourguiba as president in 1987 there was a new press code (promulgated 1988) and an easing of restrictions, and then from 1993 a limited group of permitted opposition party newspapers.

\section{Ownership:}

The Tunisian state was a significant owner of the media. In addition to the official wire agency, Agence Tunis Afrique Presse, founded in 1961, the state-owned Societé Nouvelle d'Impression de Presse et d'Edition (SNIPE), which produced the leading French-language daily La Presse de Tunisie (generally known simply as La Presse, founded 1934) and its Arabic stablemate, Assahafah. ${ }^{(11)}$ The ruling party published L'Action (founded 1932), renamed Le Renouveau under Ben Ali, defunct since 2011. Recognized opposition parties published weekly or monthly newspapers, as did the UGTT_Echaâb (The People) — and other recognized professional bodies. Privately held media groups included Dar El Anwar, publisher of Achourouk (Arabic daily), Assabah Al Ousboui (Arabic weekly), Al-Akhbar (Arabic weekly), and El Anwar (Arabic weekly). Another major private group was Dar Assabah, publisher of the Arabic daily Essabah and the French daily Le Temps. Ben Ali's son-in-law Sakhr ElMatri bought a majority stake in the group in 2009 , keeping it technically private but practically under regime control.

Tunis Hebdo is private French weekly, which also produces a separate online paper, Webdo. Circulation figures have been and continue to be generally treated as a secret, both by state and private media groups, meaning one must be cautious in how much weight one gives to the figures that are available. Rugh offered estimates for the leading newspapers, showing that Arabic papers circulated more widely than French $^{(12)}$, unsurprisingly, but that the latter had a significant share of the newspaper market, much larger than the market for local foreign language papers in Egypt, although Rugh's focus on daily newspapers means he omits the important Al-Ahram Weekly from Egypt in 2003. Radio began in Tunisia under the French protectorate, in 1939. After independence, the service was entirely state-owned and focused on development goals. Radio Nationale was joined by a multilingual broadcaster in 1960, Radio Tunis Chaîne Internationale (RTCI), a youth station in 1995, and a cultural station in 2006. The state also established four regional stations, starting with Radio Sfax in 1961, adding Monastir (Bourguiba's hometown) in 1977, Gafsa in 1991, and Tataouine in 1993. Licenses for private stations were first issued in 2003, and only to 
Ben Ali's family members or close associates, including music and variety stations like Shems FM and the Islamic Al Zitouna (another Sakhr El-Matri project). Independent broadcasters operated online without licenses, from outside the country for much of the time, until the 2011 uprising: Radio 6 Tunis (2007) and Kalima (2008). Television was introduced in 1966, offering information and entertainment, but still with a development focus, in Arabic and French ${ }^{(13)}$. Terrestrial television was and remains entirely state-owned. The main national television channel, renamed Tunisie 7 after the Ben Ali coup of November 7, 1987, was joined under his presidency by a youthand sport-oriented Tunisie 21.5 State radio and television were completely controlled.

Tunisia was an Internet pioneer in the Arab world, with its first access in 1991, and the number of users rising from around 100,000 in 2000 to 953,000 in 2006 to over four million, almost 40 percent of the population, by $2012^{(14)}$. Warf and Vincent note Tunisia as a pioneer in the region also in restricting access to Internet resources and closely monitoring users. As early as 2002, Tunisia sentenced a journalist and "cyber-activist," Zohair Ben Said al Yehiawy, to 30 months in prison for criticizing the judiciary and police. The regime invested in some of the most sophisticated web filtering and monitoring technology in the world, intervening very actively in citizens' online activities, although savvy activists and others often found ways around some of those limits. The existence of private newspapers and magazines and the emergence of private radio and satellite television stations over the last decade of Ben Ali's rule might lead one to imagine that Tunisia's media ecology was diverse and therefore liberalizing, responding to the technological and political pressures from outside and within by opening up the space for a broader national conversation, even a genuine public sphere in the classical European sense. There was a more consistent tradition of mixed public and private sector printed media in Tunisia than in Egypt, and now electronic broadcast media were also seeing such a mix emerging. But both stateowned media and private media were ruthlessly controlled under Ben Ali, in ways I discuss later. Ben Ali was to some extent an economic liberalizer, but the way he pursued economic opening allowed next to no political opening. In terms of mixed patterns of ownership don't in practice place Tunisia outside the "regulated" category: market forces were not allowed to operate in the media sector in any meaningful way $^{(15)}$.

In early 2010, Reporters without Borders (RSF) reported "Virtually the entire media landscape is under the direct control of the government or owned by those close to the president." Nor was there any significant easing of limits on content. This was tightly managed liberalization of the media sector in the economic sense only. The most significant diversification of ownership was in the electronic broadcast media, where new licenses were granted to a limited group for radio and satellite television stations, as part of what Guaaybess depicts as a controlled political opening "for the sake of the economy and the image abroad."(16) 


\section{*France}

French Republic ${ }^{(17)}$ république Française, its capital is Paris.

Situated in Western Europe, France is the second-largest country on the continent, France's capital city, Paris, is located in the north central part of the country.

The population of France in 2005 was estimated by the United Nations (UN) at $60,742,000$, which placed it at number 21 in population among the 193 nations of the world. In 2005 , approximately $16 \%$ of the population was over 65 years of age, with another $19 \%$ of the population under 15 years of age $\mathrm{e}^{(18)}$.

The French are generally derived from three basic European ethnic stocks: Celtic, Latin, and Teutonic (Frankish). There are also small groups of Flemings, Catalans, Germans, Armenians, Roma, Russians, Poles, and others. The largest resident alien groups are Algerians, Portuguese, Moroccans, Italians, Spaniards, Tunisians, and Turks ${ }^{(19)}$.

Under the constitution of the Fifth Republic (1958), as subsequently amended, the president of the republic is elected for a five-year term (changed from a seven-year term following a referendum on 24 September 2000) by direct universal suffrage. If no candidate receives an absolute majority of the votes cast, a runoff election is held between the two candidates having received the most votes. If the presidency falls vacant, the president of the Senate assumes the office until a new election can be held within 20-35 days. The president appoints the prime minister and, on the prime minister's recommendation, the other members of the cabinet. The president has the power to dissolve the National Assembly, in which event new elections must be held in 20-40 days.

When the national sovereignty is gravely menaced, the president is empowered to take special measures after consultation with the premier and other appropriate officials. The National Assembly, however, may not be dissolved during the exercise of exceptional powers. The president promulgates laws approved by the legislature, has the right of pardon, and is commander of the armed forces.

\section{POLITICAL PARTIES}

Broadly, since the late 1950s, French politics has been dominated by four political groups: the Gaullists, an independent center-right coalition, the Socialists, and the Communists. After the parliamentary elections of 23 and 30 November 1958, the first to be held under the constitution of the Fifth Republic, the largest single group in the Assembly was the Union for the New Republic (UNR) ${ }^{(20)}$, which stood for the policies of Gen. de Gaulle, elected president of the republic for a seven-year term in 1958. Independents of the right were the second-largest group, and the Christian Socialists (Mouvement Républicain Populaire) and several leftist groups followed. Only 16 members were elected by the center groups and only 10 were Communists ${ }^{(21)}$.

In the November 1962 elections, the Gaullist UNR scored an unparalleled victory, polling $40.5 \%$ of the total votes cast. As a result of the elections, several old parliamentary groups disappeared, and new groups emerged: the Democratic Center (Centre Démocratique) with 55 seats; the Democratic Rally (Rassemblement 
Démocratique), 38 seats; and the Independent Republicans (Républicains Indépendants-RI), 33 seats. The UNR and the Democratic Workers Union (Union Démocratique du Travail-UDT), left-wing Gaullists, agreed to a full merger of their parties and together controlled 219 seats $^{(22)}$.

In the first presidential elections held by direct universal suffrage in December 1965, President de Gaulle was reelected on the second ballot with $55.2 \%$ of the total vote. In the March 1967 general elections, the UNR-UDT gained 246 seats against 116 for the Socialists and 73 for the Communists. Following nationwide strikes and civil disturbances by workers and students in the spring of 1968, new parliamentary elections were held in June, in which de Gaulle's supporters won a sweeping victory.

On 2 April 1974, President Pompidou died. In elections held on 5 May, Gaullist candidate and former premier Jacques Chaban-Delmas was defeated, receiving only $15 \%$ of the votes cast. The leader of the leftist coalition, François Mitterrand, received over 11 million votes, and Valéry Giscard d'Estaing, the leader of the RI, over 8 million. However, as neither had won a majority, a run-off election was held on 19 May. Giscard, with the help of Gaullist votes, defeated Mitterrand by a margin of $50.7 \%$ to $49.3 \%$. Jacques Chirac of the UDR was made premier, with a cabinet made up mainly of RI and UDR members.

In 1995, Jacques Chirac was elected president, defeating Socialist Lionel Jospin. In 1997, one year before they were scheduled, Chirac called for new parliamentary elections, hoping to achieve a mandate to inaugurate his policy of fiscal austerity. Instead, the Gaullists suffered a stunning defeat by the Socialists and Communists, leading to the appointment of Jospin as prime minister. In those elections, held 25 May and 1 June 1997, the Gaullists saw their parliamentary presence decline from 464 seats to 249; the Socialists (and related splinter groups) went from 75 seats to 273; the Communists from 24 to 38; the Greens from no seats to 8; and the far-right National Front maintained its single seat.

The first round of presidential elections were held on 21 April 2002, with Jospin coming in third behind National Front leader Jean-Marie Le Pen and Jacques Chirac in the first round. Two days after these results, on 23 April 2002, the Union en Mouvement (Union in Motion-UEM) was dissolved and replaced by the Union pour la majorité présidentielle (Union for Presidential Majority-UMP) in order to create a major public support behind Chirac in his second round face-off with Le Pen. In May 2002, Jacques Chirac defeated Jean-Marie Le Pen in the second round, taking $82.2 \%$ of the vote to Le Pen's $17.8 \%{ }^{(23)}$.

In the National Assembly elections held in June 2002, Chirac's UMP (RPR united with the Liberal Democracy party, formerly the Republican Party) won an overwhelming majority of seats, taking 357 to the Socialists' 140. The National Front failed to win a single seat; the UDF held 29 seats and the Communists took 21 . The Greens held only three seats.

On 17 November 2002, the UMP changed its name to Union pour un Mouvement 
Populaire (Union for a Popular Movement), keeping the same acronym but modifying the out-of-date appellation.

Its first test occurred in March 2004, during the cantonal and regional elections. While suffering a devastating loss, it managed, through alliances, to secure a relative majority of the votes.

Its second test was the European elections, also held in 2004. The UMP won only $17 \%$ of the votes, while the Socialist Party earned 29\% and the UDF (composed of members that refused to join in the UMP) reached $12 \%$. The UDF's relative success was largely caused by the attractive alternative that it offered voters that were unhappy with the government's take on social and European issues.

The relative slump of the right can also be explained by the rise of popularity of the National Front and the unpopularity generated by the Raffarin governments.

\section{The organizational structure of the French media:}

Postal, telephone, and telegraph systems are operated by the government under the direction of the Ministry of Post, Telegraph, and Telephones. In 2003, there were an estimated 566 mainline telephones for every 1,000 people. The same year, there were approximately 696 mobile phones in use for every 1,000 people ${ }^{(24)}$.

The government-controlled Office de Radio diffusion-Télévision Française was replaced in January 1975 by seven independent state-financed companies. A law of July 1982 allowed greater independence to production and programming organizations. Under deregulation, many private radio stations have been established. Of the three state-owned television channels, TF-1, the oldest and largest, was privatized in 1987; a fourth, private channel for paying subscribers was started in 1984. Contracts were awarded in 1987 to private consortiums for fifth and sixth channels. As of 1999 there were $41 \mathrm{AM}$ and $800 \mathrm{FM}$ radio stations (many of the FM stations were repeaters) and 310 TV stations. In 2003, there were an estimated 950 radios and 632 television sets for every 1,000 people. About 57.5 of every 1,000 people are cable subscribers. Also in 2003 , there were 347.1 personal computers for every 1,000 people and 366 of every 1,000 people had access to the Internet. There were 3,855 secure Internet servers in the country in 2004.

Traditionally, the French press falls into two categories. The presse d'information, with newspapers with the largest circulation, emphasizes news; the presse d'opinion, usually of higher prestige in literary and political circles but of much lower daily circulation, presents views on political, economic, and literary matters. In 2002, there were over 100 dailies in the country. Some of the important regional papers rival the Parisian dailies in influence and circulation.

Leading national newspapers (with their organizational affiliation and 2005 circulation totals unless noted) are: Le Figaro (moderate conservative, 326,800), Le Monde (independent, elite, 324,400), International Herald Tribune (English-language, 210,000 in 2002), Liberation (135,600), L'Humanit é (Communist, 49,500), and La Croix (Catholic, 98,200 in 2002). Some leading regional dailies include Ouest-France (in Rennes, mass-appeal, 761,100 in 2005), La Voix du Nord (in Lille, conservative, 356,903 in 2004), Sud-Ouest (in Bordeaux, independent, 359,300 in 2002), Nice- 
Matin (in Nice, radical independent, 243,800 in 2002), Les Dernieres Nouvelles D’Alsace (in Strasbourg, 215,460 in 2004), La Dépêche du Midi (in Toulouse, radical, 218,214 in 2004), and Le Telegramme (in Morlaix, 199.710 in 2004). L'Express and Le Point are popular news weeklies.

The Agence France-Presse is the most important French news service. It has autonomous status, but the government is represented on its board of directors. There are some 14,000 periodicals, of which the most widely read is the illustrated Paris-Match, with a weekly circulation (in 1995) of 868,370. Several magazines for women also enjoy wide popularity, including Elle, (1995 circulation 360,000). Also for women are magazines publishing novels in serial form. The most popular political weeklies are L'Express (left-wing), with a circulation of about 419,000; the satirical Le Canard Enchaîné (left-wing), circulation 500,000; Le Nouvel Observateur (left-wing), circulation 399,470; and the news-magazine Le Point (independent), circulation 280,770. Filmmaking is a major industry, subsidized by the state ${ }^{(25)}$.

The law provides for free expression including those of speech and press, and these rights are supported by the government.

\section{Poland:}

Its official name is Rzeczpospolita Polska (Republic of Poland) as for its form of government its Unitary multiparty republic with two legislative houses (Senate [100]; Sejm $[460])^{(26)}$.

Capital;Warsaw, Poland is a country of central Europe which is located at a geographic crossroads that links the forested lands of northwestern Europe to the sea lanes of the Atlantic Ocean and the fertile plains of the Eurasian frontier. Now bounded by seven nations, Poland has waxed and waned over the centuries, buffeted by the forces of regional history. In the early middle Ages, Poland's small principalities and townships were subjugated by successive waves of invaders, from Germans and Balts to Mongols. In the mid-1500s, united Poland was the largest state in Europe and perhaps the continent's most powerful nation. Yet two and a half centuries later, during the Partitions of Poland (1772-1918), it disappeared, parceled out among the contending empires of Russia, Prussia, and Austria ${ }^{(27)}$.

\section{POLITICAL PARTIES}

Poland is a representative democracy, with a president as a head of state, whose current constitution dates from 1997. Poland ranks in the top 20 percent of the most peaceful countries in the world, according to the Global Peace Index. The government structure centers on the Council of Ministers, led by a prime minister ${ }^{(28)}$. The president appoints the cabinet according to the proposals of the prime minister, typically from the majority coalition in the Sejm. The president is elected by popular vote every five years. The current president is Andrzej Duda and the prime minister is Mateusz Morawiecki.

Polish voters elect a bicameral parliament consisting of a 460-member lower house (Sejm) and a 100-member Senate (Senat). The Sejm is elected under proportional 
representation according to the d'Hondt method, a method similar to that used in many parliamentary political systems ${ }^{29}$. The Senat, on the other hand, is elected under the first-past-the-post voting method, with one senator being returned from each of the 100 constituencies.

Sejm is the lower house of the Polish parliament.

With the exception of ethnic minority parties, only candidates of political parties receiving at least $5 \%$ of the total national vote can enter the Sejm. When sitting in joint session, members of the Sejm and Senat form the National Assembly (the Zgromadzenie Narodowe). The National Assembly is formed on three occasions: when a new president takes the oath of office; when an indictment against the President of the Republic is brought to the State Tribunal (Trybunał Stanu); and when a president's permanent incapacity to exercise his duties due to the state of his health is declared. To date only the first instance has occurred.

The judicial branch plays an important role in decision-making. Its major institutions include the Supreme Court (Sąd Najwyższy); the Supreme Administrative Court (Naczelny Sąd Administracyjny); the Constitutional Tribunal (Trybunał Konstytucyjny); and the State Tribunal (Trybunał Stanu). On the approval of the Senat, the Sejm also appoints the ombudsman or the Commissioner for Civil Rights Protection (Rzecznik Praw Obywatelskich) for a five-year term. The ombudsman has the duty of guarding the observance and implementation of the rights and liberties of Polish citizens and residents, of the law and of principles of community life and social justice $^{(30)}$.

The constitution of Poland's postwar socialist state, the Polish People's Republic, took effect in 1952 but was amended numerous times, most significantly in early 1989, when constitutional reforms worked out between the government and Solidarity were passed by the Sejm (legislature). Among the changes were the replacement of the Council of State by the office of president (a position that had been eliminated in 1952) and the reinstatement of the Senate, which had been abolished in 1946 in an allegedly rigged national referendum. The existing Sejm, with 460 members, became the lower house of the new legislature, and the Senate, or the upper house, was assigned 100 members. Additional reforms passed later in 1989 by the legislature included the guarantee of free formation of political parties and the return of the state's official name to the Republic of Poland.

The new constitution of 1997, which replaced a 1992 interim constitution, was adopted in April by the National Assembly (Zgromadzenie Narodowe; as the Sejm and the Senate are referred to when they meet in a joint session to debate constitutional issues), approved in a national referendum in May, and promulgated in October. The constitution confirmed the mixed presidential-parliamentary form of government that had been established during the period 1989-92. Under its provisions the president is directly elected to not more than two five-year terms. The president serves as 
commander in chief of the armed forces, has the power (albeit restricted) to declare martial law or a state of emergency, and can veto an act of the Sejm (which in turn can override that veto with a three-fifths majority vote).

The president nominates the prime minister and, on the prime minister's recommendation, the cabinet, subject to the Sejm's approval, but the president cannot dismiss the government. Deputies in the Sejm and senators are popularly elected to four-year terms. Laws must be adopted by both houses. The Senate has the right to amend or reject a law passed by the Sejm. The Sejm may override the Senate's decision with a majority vote. The Sejm appoints the members of the Constitutional Tribunal, the commissioner for civil rights protection (the ombudsman), the chairman of the Supreme Chamber of Control (the state audit commission), and the president of the Bank of Poland. The main executive power is vested in the prime minister and the Council of Ministers, who are responsible to the Sejm. The government can be terminated by the Sejm only by a constructive vote of no confidence. The prime minister has a role comparable to that of a chancellor in the German political system.

\section{The organizational structure of the Polish media:}

Poland has a number of major media outlets, chief among which are the national television channels. TVP is Poland's public broadcasting corporation; about a third of its income comes from a broadcast receiver license ${ }^{31}$, while the rest is made through revenue from commercials and sponsorships. State television operates two mainstream channels, TVP 1 and TVP 2, as well as regional programs for each of the country's 16 voivodeships (as TVP 3). In addition to these general channels, TVP runs a number of genre-specific programmes such as TVP Sport, TVP Historia, TVP Kultura, TVP Rozrywka, TVP Seriale and TVP Polonia, the latter is a state-run channel dedicated to the transmission of Polish language television for the Polish diaspora abroad ${ }^{(32)}$.

Intel Extreme Masters, an eSports video game tournament in Katowice

Poland has several 24-hour news channels: Polsat News, Polsat News 2, TVP Info, and TVN 24 TVN 24 Biznes i Świat, TV Republika and WPolsce.pl.

In Poland, there are also daily newspapers like Gazeta Wyborcza ("Electoral Gazette"), Rzeczpospolita ("The Republic") and Gazeta Polska Codziennie ("Polish Daily Newspaper") which provide traditional opinion and news, and tabloids such as Fakt and Super Express. Rzeczpospolita, founded in 1920 is one of the oldest newspapers still in operation in the country. Weeklies include Tygodnik Angora, W Sieci, Polityka, Wprost, Newsweek Polska, Gość Niedzielny and Gazeta Polska.

Poland also has emerged as a major hub for video game developers in Europe, with the country now being home to hundreds of studios. One of the most popular video game series developed in Poland includes The Witcher. Katowice hosts Intel Extreme Masters, one of the biggest eSports events in the world ${ }^{(33)}$.

Under the communist government, the Main Office for the Control of the Press, Publications, and Public Performances (GUKPIW), headquartered in Warsaw, 
controlled the media, publishing, films, theatres, exhibitions, advertising, and related activities. The bureau maintained an office in all television and radio stations, press and publishing houses, film and theatre studios, and printing establishments throughout the country. Authorization was required even for such printed items as wedding invitations, obituary notices, and stationery. The government closely controlled access to photocopiers and printing machines, and all purchases of paper in bulk required a permit. Censorship of foreign mail was routine ${ }^{(34)}$. No sphere of information was immune, however distant from immediate political concerns; censors attempted not only to suppress material but also to mold all information at its source.

The Polish press included the official organs of the party and state, such as Trybuna Ludu ("People's Tribune"), the organ of the PUWP, and a variety of less closely controlled semiparty newspapers and journals, such as Życie Warszawy ("Warsaw Life"), Polityka ("Politics"; a lively weekly), and Twórczość ("Creativity"; an intellectual monthly). Despite the official controls, speech was not generally suppressed in Poland, and the highly literate Poles became masters at writing and reading "between the lines." Moreover, alternative perspectives were offered in the respected independent Kraków publication Tygodnik Powszechny ("Universal Weekly"), in the Roman Catholic journals Znak ("The Sign") and Więż ("The Link"), and in the underground "free sector." The latter developed in the 1970s and 1980s into a vast network, publishing everything from books banned by the regime to academic journals and local newssheets.

Restrictions on the media eased in 1989, and Solidarity supporters began publishing numerous journals and newspapers, including the daily newspaper Gazeta Wyborcza ("Voters Daily"; Eng. ed. Gazeta International). In 1990 the state abandoned censorship of the press, and this led to the appearance of a wide range of new publications. Though in the 1990s the number of newspaper titles was reduced by half, the number of books and magazines doubled. The private sector in both broadcast and print media has grown rapidly, in great part owing to foreign investments. It includes television and radio stations, national and regional newspapers and magazines, and publishing houses. Many communities publish local newsletters and bulletins. Rzeczpospolita ("The Commonwealth") is a semiofficial newspaper of record.

\section{b) Economical environment:}

\section{*Greece}

Greece is a country in southeastern Europe with thousands of islands throughout the Aegean and Ionian seas. Influential in ancient times, it's often called the cradle of Western civilization. Athens, its capital, retains landmarks including the 5th-century B.C. Acropolis citadel with the Parthenon temple. Greece is also known for its beaches, from the black sands of Santorini to the party resorts of Mykonos ${ }^{(35)}$.

Capital: Athens

Currency: Euro

Official language: Greek 


\section{The Economical status:}

The world economy has experienced great volatility and uncertainty during the last eight years ${ }^{(36)}$.

The global financial crisis of 2008, which originated in the United States of America, has been followed by a severe debt crisis in Europe that affected national economies in different ways, indicating the ruptures between the centre (e.g., Germany) and the periphery (e.g., Greece, Spain). Indicatively, the unemployment rate in Greece has soared to record levels, from 8 percent in 2008 to 28 per cent in 2013, and similarly from 11 per cent to 26 per cent in Spain, while in contrast in Germany, it decreased from 7.5 per cent to 5.3 per cent (Eurostat 2014a). Consequently, the negative repercussions of the global economic crisis were transmitted to regions and localities, while the enforcement of austerity policies further emphasized their vulnerability to external disturbances.

The strong asymmetric impacts of recessionary shocks on regional labour markets have contributed to the popularity of the resilience concept ${ }^{(37)}$. Resilience can be defined as the capacity of a system to absorb disturbance, to reorganize and to retain its basic function, structure and identity ${ }^{(38)}$. Currently, the concept of resilience has gained prominence in regional studies in the context of understanding how local economies react to and recover from recessionary shocks ${ }^{(39)}$

Several factors affect the magnitude of the external upheaval in the regions such as the sectoral composition of the economy, the skills of the workforce, the innovation rate and the institutional arrangements within regions ${ }^{(40)}$

Greece has 13 NUTS 2 regions, the main socioeconomic characteristics of which are summarized in Table 1. Following the OECD typology, 77 per cent of Greek regions

ध. are classified as predominantly rural, while the corresponding percentage in Europe is only 35 per cent (OECD 2013). Only the Attiki region, where the capital is located, is characterized as predominantly urban, while the regions of Kentriki Makedonia (the region of the sub-capitalThessaloniki) and Thessalia are characterized as intermediate.

Greece exhibited severe and multifaceted regional disparities at inter-regional and intraregional level before the economic crisis. The physical geography of the country, that is, the combination of mountainous, island and remote regions, but mainly the domination of a dualistic economic base, with the prevalence of Athens and Thessaloniki urban systems, widened regions'asymmetries ${ }^{41}$. The presence of such territorial imbalances suggests that Greek regions did not evolve homogeneously, while the impact of the economic integration had not been evenly distributed. Petrakos and Saratsis $(2000)^{42}$ support that regional inequalities in Greece have a pro-cyclical character, that is, increasing in periods of economic growth and decreasing in periods of economic recession.

The rapid growth of the Greek economy during the last decades was based on the concentration of resources, both financial and human, in the two big urban centres, that is, Athens and Thessaloniki, which further widened existing regional disparities. The current economic crisis exposed the country's vulnerabilities but also shed new light on the way the economy functions.

Many papers indicate that policy-makers should pay more attention to rural regions. 
Regional resilience is not necessarily associated with more urbanization ${ }^{(43)}$. However, the long-term success of rural territories depend on a number of key drivers such as innovation, human capital, natural resources, infrastructures, economic diversity and policy support. The current regional policy agenda of the EU 2020 strategy towards an inclusive, smart and sustainable Europe is based on the effective use of territorial assets and local endowments for further strengthening local responses and reducing vulnerability to external factors. One of the most important assets of rural areas is land under agricultural management.

\section{The organizational structure of the Greek media:}

The media of Greece refers to mass media outlets based in the Republic of Greece. Television, magazines, and newspapers are all operated by both state-owned and forprofit corporations which depend on advertising, subscription, and other sales-related revenues. The Constitution of Greece guarantees freedom of $\operatorname{speech}^{(44)}$.

Press freedom sharply eroded in Greece during the economic and financial crisis of 2010-2015, passing from the 35th place in 2009 in Reporters Without Borders Press Freedom Index to the 99th place in 2014, well below all Western Balkans countries as well as states with repressive media policies such as Gabon, Kuwait or Liberia.

Greece is today the EU member state "where journalism and the media face their most acute crisis"(45).

In Greece, the "levels of concentration of media ownership and cross-media concentration are high". The main reason for is lies in the diversification and deregulation process which led several newspaper groups to invest in electronic media. This happened in a poorly regulated media environment ${ }^{(46)}$.

As for the print sector, the three largest press groups - Lambrakis Press SA (DOL), Tegopoulos Publishing, and Pegasus SA (Bobolas family) - are also shareholders in the main terrestrial channel MEGA. Press Institution SA holds shares in terrestrial channel STAR, and the Alafouzos family owns terrestrial channel SKAI and several radio stations. The rise of the Internet has added a concentration problem as the highest-visited websites include those of the mainstream publishing groups like DOL, Pegasus and also MEGA chennel. In the last decade, the problem of media concentration worsened significantly ${ }^{(47)}$, as demonstrated by the following data: in 2008 the four leading publishing house controlled $69.7 \%$ of the market compared to $57.3 \%$ in $2000,62.9 \%$ in 1995 and $59 \%$ in 1990 . The publishers of such outlets adopted a diversification strategy, leading to investment into other different sectors and industries.

As for the broadcasting sector, after the deregulation process of the late 1980s, the number of private television stations increased significantly. However, despite the large number of media outlets, the media scene is dominated by five private channels (MEGA, Ant1, Alpha, Star and Alter) belonging to conglomerates with activities also in other sectors. 
Concerning the regulation of media concentration, the relevant law, i.e. Law 2328/1995 did not prevent high levels of concentration, whereas the more recent Law 3592/2007 named "New Act on concentration and Licensing of Media Undertakings" provided more opportunities for deregulation and market liberalization by abolishing some older regulations. A 2014 amendment to the above Law further relaxed ownership and cross-media ownership requirements by allowing partnerships between electronic media businesses of the same type (television, online, or radio) if this results in a cut of operating costs (through economies of scale or joint utilization of financial resources). This is an indicator of the government's intention to create large media conglomerates for economic viability.

\section{c) Journalistic environment:}

\section{*Russia}

Russia, the world's largest nation, borders European and Asian countries as well as the Pacific and Arctic oceans. Its landscape ranges from tundra and forests to subtropical beaches $^{(48)}$. It's famous for Moscow's Bolshoi and St. Petersburg's Mariinsky ballet companies. St. Petersburg, founded by Russian leader Peter the Great, has the baroque Winter Palace, now housing part of the State Hermitage Museum's art collection.

Capital: Moscow

Population: 144.3 million (2016) World Bank

Russia, country that stretches over a vast expanse of eastern Europe and northern Asia. Once the preeminent republic of the Union of Soviet Socialist Republics (U.S.S.R.; commonly known as the Soviet Union), Russia became an independent country after the dissolution of the Soviet Union in December $1991^{(49)}$.

The inhabitants of Russia are quite diverse. Most are ethnic Russians, but there also are more than 120 other ethnic groups present, speaking many languages and following disparate religious and cultural traditions. Most of the Russian population is concentrated in the European portion of the country, especially in the fertile region surrounding Moscow, the capital. Moscow and St. Petersburg (formerly Leningrad) are the two most important cultural and financial centres in Russia and are among the most picturesque cities in the world. Russians are also populous in Asia, however; beginning in the 17th century, and particularly pronounced throughout much of the 20th century, a steady flow of ethnic Russians and Russian-speaking people moved eastward into Siberia, where cities such as Vladivostok and Irkutsk now flourish ${ }^{(50)}$.

\section{The journalistic environment \& organizational structure of the Russian media:}

Russian 19th-century journalism was extremely vigorous, with newspapers and monthly "thick" journals being the most important forums. Daily newspapers and monthly journals of all political and artistic stripes continued to appear in the immediate aftermath of the 1917 revolution $^{(51)}$. However, the state's desire to control sources of information and propaganda manifested itself quickly, and most independent publications were eliminated by the early 1920s. What remained were the ubiquitous daily duo of Pravda ("Truth") and Izvestiya ("News"). Journals were in a somewhat better position, especially those that published mostly works of literature. 
Periodicals such as Krasnaya nov ("Red Virgin Soil") and LEF ("The Left Front of Art") published much significant literature in the 1920s. In the 1960s this tradition was revived by the journal Novy mir ("New World"), which in the 1980 s was joined by a revitalized Ogonyok ("Spark"), though the latter was only briefly innovative ${ }^{(52)}$.

Radio and television from the time of their appearance in the Soviet Union were heavily dominated by the Communist Party apparatus and were seen as primary tools for propaganda. Until the mid-1980s most television programming consisted of either direct or indirect propaganda spiced with high art (e.g., filmed concerts and plays) and occasional grade-B thriller motion pictures.

During the glasnost period groundbreaking television programming helped create the situation in which the Soviet state was destroyed. Government control of the media began to weaken, and by 1989 official censorship had been completely abolished. A significant portion of the press was privatized, but important elements still remained under the control and regulation of the government, particularly the television news media. Among the leading newspapers, Rossiyskaya Gazeta ("Russian Newspaper") is the government's official organ and enjoys wide circulation. Independent newspapers, such as the weekly Argumenty i Fakty ("Arguments and Facts"), the daily Moskovskii Komsomolets ("Moscow Komsomol"), and Nezavisimaya Gazeta ("Independent Newspaper"), also exert influence and are widely read. Pravda declined in significance during the 1980s, and Komsomolskaya Pravda ("Komsomol Truth") and Sovetskaya Rossiya ("Soviet Russia") became the principal news sources for Russian communists. There are also several independent newspapers (e.g., The Moscow Times) that publish in English ${ }^{(53)}$.

In the early post-Soviet years, Russian television exhibited signs of independence from the central government, but by the mid-1990s the Yeltsin government was exerting considerable influence. Much of Russian television is under state control; for example, Russian Public Television (Obschestvennoye Rossiyskoye Televideniye; ORT) is owned by the state, and another channel, commonly called Russian TV, is operated by the state-run Russian State Television and Radio Broadcasting Company (Vserossiyskaya Gosudartstvennaya Teleradiokompaniya). There were also several independent commercial television stations, some with wide viewership, such as Independent Television (Nezavisimoye Televideniye; NTV) and TV-6, both of which were available throughout Russia. Moreover, there were several hundred television stations that broadcast only regionally or locally. Some independently owned outlets that criticized the government found themselves the subject of official harassment during the presidency of Vladimir Putin; for example, TV-6 was ordered to cease broadcasting, and media tycoons Vladimir Gusinsky and Boris Berezovksy lost their media holdings and were forced into exile. The government operates two press agencies, ITAR-TASS, which succeeded the Soviet-era TASS agency, and the Russian Information Agency-Novosti. 


\section{References:}

1. "Tunisia." History | Data, data.worldbank.org/country/tunisia.

2. "Tunisia - Land | history - geography". Encyclopedia Britannica. Retrieved 2018-09-07.

3. “Tunisia Country Profile.” BBC News, BBC, 14 Jan. 2018, www.bbc.com/news/ world-africa-14107241.

4. Alexis Arieff, Carla E. Humud, 'Political Transition in Tunisia", February 10, 2015.

5. Available at : https://www.fas.org/sgp/crs/row/RS21666.pdf

6. Frosini, Justin; Biagi, Francesco (2014). Political and Constitutional Transitions in North Africa: Actors and Factors. Routledge. p. 4. ISBN 978-1-317-59745-2.

7. "National Institute of Statistics-Tunisia". National Institute of Statistics-Tunisia. 12 September 2016. Archived from the original on 4 September 2015. Retrieved 08 September 2018.

8. Tunisia | Country report | Freedom in the World | 2015". freedomhouse.org. Retrieved 08 September 2018.

9. Houda Trabelsi (5 October 2010). "Shems FM hits Tunisia airwaves”. Magharebia. com. Retrieved 10 September 2018.

10. "Presse et communication en Tunisie" (in French). Tunisie.com. Archived from the original on 19 March 2012. Retrieved 10 September 2018.

11. Rugh , William A. Arab Mass Media . Greenwood Publishing Group (1757), 2004.

12. “The Global Competitiveness Report 2008-2009”. Weforum.org. Retrieved 08 September 2018.

13. Rugh , William A. Arab Mass Media . Greenwood Publishing Group (1757), 2004

14. Warf, Barney, and Peter Vincent. "Multiple Geographies of the Arab Internet." Area, vol. 39, no. 1, 2007, pp. 83-96., doi:10.1111/j.1475-4762.2007.00717.x.

15. Monia Ghanmi, "Tunisia Fosters Media Pluralism," Maghrebia, July 7, 2011

16. “Tunisian TV Mogul Fined Over 'Blasphemous' Film,” Telegraph, May 16, 2012, www.telegraph.co.uk/news/worldnews/africaandindianocean/tunisia/9244054/ Tunisian-TV-mogul-fined-over-blasphemous-film.html.

17. "France." World mark Encyclopedia of Nations. 2007. Retrieved December 07, 2015 from Encyclopedia.com: http://www.encyclopedia.com/ doc/1G2-2586700268.html

18. "A French Islam is possible". Institut Montaigne. 2016. p. 13.

19. "2016 Human Development Report" United Nations Development Programme. 2016. Retrieved 09 September 2018.

20. Helen Drake (2011). Contemporary France. Palgrave Macmillan. p. 95. doi:10.1007/978-0-230-36688-6. ISBN 978-0-333-79243-8.

21. "France: Strict Defamation and Privacy Laws Limit Free Expression - Index on Censorship | Index on Censorship." France: Strict Defamation and Privacy Laws Limit Free Expression - Index on Censorship | Index on Censorship. N.p., n.d. Web. 26 February 2014. 
22. "France votes to ban full-face veils". Amnesty International. 13 July 2010.

23. "Election of deputies". Assemblée Nationale.

24. (in French) OJD, "Observatoire de la Presse", Presse Quotidienne Nationale Archived 8 August 2018 at the Wayback Machine.

25. The Telegraph, Nicolas Sarkozy: French media faces 'death' without reform 2 October 2008

26. Rykała, Andrzej (2014). "National and Ethnic Minorities in Poland from the Perspective of Political Geography". Acta Universitatis Lodziensis. Folia Geographica Socio-Oeconomic. 17: 63-111 - via CEON Biblioteka Nauki.

27. "Population. Size and structure and vital statistics in Poland by territorial division in 2017. As of December 31". stat.gov.pl."5. Report for Selected Countries and Subjects". International Monetary Fund. Retrieved 10 September 2018.

28. Davies, Norman (1996). Europe: A History. Oxford University Press. p. 699. ISBN 0-19-820171-0 - via Google Books.

29. Norman Davies (1996). Europe: A History. Oxford University Press. p. 699. ISBN 0-19-820171-0.

30. Reuters, Ukraine, Poland and Lithuania form joint military unit. Warsaw, 19 September 2014.

31. Adam Gopnik (5 June 2007). “Szymborska's 'View': Small Truths Sharply Etched”. npr.org. Retrieved 12 September 2018.

32. "About White Stork". Poland.pl. Retrieved 07 September 2018.

33. Dawson, Andrew Hutchinson, and Kazimierz Maciej Smogorzewski. "Poland." Encyclopædia Britannica, Encyclopædia Britannica, Inc., 8 Sept. 2018, www. britannica.com/place/Poland/Theatre-and-motion-pictures\#ref256693.

34. Worldbank.org, Global Financial Development Report 2014. Appendix B. Key Aspects of Financial Inclusion.

35. The Strategic Importance of Greece". Geopoliticalfutures.com. Retrieved 05 September 2018.

36. Bentley G, Pugalis L (2013) New directions in economic development: Localist policy discourses and the Localism Act. Local Economy 28: 257-274

37. Hudson R (2010) resilient regions in an uncertain world: wishful thinking or a practical reality? Cambridge Journal of Regions, Economy and Society 3: 11-25

38. Folke C, Carpenter SR, Walker B, Scheffer M, Chapin T, Rockström J (2010) Resilience thinking: Integrating resilience,adaptability and transformability. Ecology and Society 15: 20

39. Martin R (2012) Regional economic resilience, hysteresis and recessionary shocks. Journal of Economic Geography 12: 1-32

40. Fingleton B, Garretsen H, Martin R (2012) Recessionary shocks and regional employment: Evidence on the resilience of UK regions. Journal of Regional Science 52: 109-133

41. Petrakos G, Fotopoulos G, Kallioras D (2008) A Southern perspective on economic integration and structural change: The case of Greek regions. In: Krieger-Boden C, Morgenroth E, Petrakos G (eds) The impact of European integration on regional structural change and cohesion. Routledge, New York 
42. Petrakos G, Saratsis Y (2000) Regional inequalities in Greece. Papers in Regional Science 79: $57-74$

43. Brakman S, Garretsen H, van Marrewijk C (2015) Regional resilience across Europe: On urbanization and the initial impact of the Great Recession. Cambridge Journal of Regions, Economy and Society 8: 225-240

44. Thomas Van Der Heijden, Media landscape in Greece must reform quickly, Euroscope, 28 November 2014

45. Petros Iosifidis and Dimitris Boucas, Media Policy and Independent Journalism in Greece (PDF), Open Society Foundation report, 1 May 2015

46. Iosifidis, P. (2010). Reinventing Public Service Communication: European Broadcasters and Beyond. London: Palgrave Macmillan.

47. BÁRD, Petra; BAYER, Judith (2016). "A comparative analysis of media freedom and pluralism in the EU Member States. Study for the LIBE Committee" (PDF). Directorate-General for Internal Policies. Policy Department Citizens' Rights and Constitutional Affairs. European Parliament. Retrieved 10 September 2018.

48. Russia”. Encyclopædia Britannica. Retrieved 31 August 2018.

49. Felix J. Oinas, "Folklore and Politics in the Soviet Union," Slavic Review 32 (1973): 45.

50. Defending Identity: Its Indispensable Role in Protecting Democracy, by Natan Sharansky, 2008, pp 139ff.

51. Fedorov, A. (2007). Model of Pedagogical University Students' Media Competence and Critical Thinking Development at Media Education Lessons. In: Innovations in Education. № 7, pp. 107-116.

52. Khudoleyeva, E. (2006). Contemporary Pedagogical Problems of Media Education in

53. Germany and Russia (the end of the 20th - the beginning of the 21 st centuries). Ph.D. thesis abstract. Vladivostok, $25 \mathrm{p}$.

54. Sokolova, N. (2004). Use of Media Education Elements at Quantum Physics Lessons. Ph.D. thesis abstract. Moscow, $18 \mathrm{p}$. 

